doctrinal position of that branch of the "Holy Church Universal" known for the time being as the "Protestant Episcopal Church in the United States of America."

But if Bishop Lee was eminent in all pertaining to his official position, he was also eminently Christian in the various relations of private life. As a husband and father he was tenderly thoughtful and affectionate; as a friend, considerate and true, and as an acquaintance and neighbor most sociable and charitable. His cheerful manners and entertaining conversation rendered his society universally attractive. His words of cheer and deeds of judicious but unostentatious benevolence cheered many an anxious heart and gladdened many a needy home.

\title{
CAMANCHE AND ALBANY FERRY.
}

The subscriber respectfully informs the traveling public, that he has in complete operation a large and commodious Ferry Boat, propelled by horse power plying between the above places, at one of the best locations for a ferry on the Mississippi, river, and on the most direct route from Chicago or in fact all the eastern travel through Iowa Territory to the settlements on Cedar, Iowa, Waubesepineca, or Macoqueta, rivers. This Boat is large and safe for teams and heavy carriages, and will land on either side of the Meridosia to accommodate passengers. - The subscriber hopes by always being in readiness to accommodate the public, to merit and receive the patronage of travellers and emigrants.

JAMES CLAIBURN,

Camanche, June 5, 1839. Proprietor.

- Iowa Sun, Davenport, November 13, 1839. 
Copyright of Annals of Iowa is the property of State of Iowa, by \& through the State Historical Society of Iowa and its content may not be copied or emailed to multiple sites or posted to a listserv without the copyright holder's express written permission. However, users may print, download, or email articles for individual use. 